\title{
SKA3 overexpression promotes cell proliferation and migration in breast cancer cell lines
}

\section{[SKA3 aşırı ekspresyonu, meme kanseri hücre hatlarında hücre proliferasyonunu ve göçünü teşvik eder]}

https://doi.org/10.1515/tjb-2020-0032

Received January 21, 2020; accepted July 13, 2020; published online September 23, 2020

\section{Abstract}

Objectives: Breast cancer (BC) is the most commonly diagnosed cancer in women worldwide with a high mortality rate, despite early detection and treatment. Spindle and kinetochore-associated complex subunit 3 (SKA3) is closely correlated with patient outcomes in several cancers. The present study aimed to elucidate the role of SKA3 in BC. Methods: The biological functions of SKA3 was investigated by proliferation and migration assays in MDA-MB231 cells with stable SKA3 knockdown and Hs578T cells ectopically expressing SKA3. Gene Expression Omnibus datasets were utilised to determine the correlation between SKA3 expression and clinical features of BC patients.

Results: We confirmed that SKA3 mRNA expression is higher in breast tumour tissue than in normal tissue, and that higher SKA3 expression is associated with poor survival rate of BC patients. Knockdown of SKA3 reduced MDA-MB-

\footnotetext{
*Corresponding author: Sungguan Hong, Ph.D., Department of Chemistry, Chung-Ang University, Seoul 06974, South Korea.

Phone: +82 2820 5923, Fax: +82 2825 4736,

E-mail: sungguanhong@cau.ac.kr. https://orcid.org/0000-00027144-6478

Jaeyong Kang, Hansaem Kim, Hyangsoon Noh and Byung-Ha Kang, Department of Chemistry, Chung-Ang University, Seoul 06974, South Korea

Jaejik Kim, Department of Statistics, Sungkyunkwan University, Seoul, South Korea
}

231 cell proliferation and migration, whereas SKA3 overexpression enhanced the proliferative and migratory ability of Hs578T cells. We also found that SKA3 is involved in regulating cell cycle progression in mitotic exit.

Conclusions: These results suggest that SKA3 is correlated with $\mathrm{BC}$ cell proliferation and migration by promoting cell cycle progression, and could be a novel potential therapeutic target for $\mathrm{BC}$ treatment.

Keywords: breast cancer; cell migration; cell proliferation; poor prognosis.

\section{öz}

Giriş: Meme kanseri (BC), erken tespit ve tedaviye rağmen, yüksek mortalite oranı ile dünya çapında kadınlarda en sık teşhis edilen kanserdir. Kromozomların bağlandığı lifler ve kinetokor ile ilişkili kompleks alt birim 3 (SKA3), çeşitli kanser türlerinde hasta sonuçlarıyla yakından ilişkilidir.

Amaç: Bu çalışma, SKA3'ün BC'deki rolünü aydınlatmayı amaçlamaktadır.

Yöntemler: SKA3'ün biyolojik fonksiyonları, stabil SKA3 knockdown'lu MDA-MB-231 hücrelerinde ve SKA3'ü ektopik olarak eksprese eden Hs578T hücrelerinde proliferasyon ve migrasyon deneyleri ile araştırıldı. Gen İfadesi Omnibus veri setleri, BC hastalarının SKA3 ekspresyonu ile klinik özellikleri arasındaki ilişkiyi belirlemek için kullanıldı.

Bulgular: SKA3 mRNA ekspresyonunun göğüs tümör dokusunda normal dokudan daha yüksek olduğunu ve daha yüksek SKA3 ekspresyonunun BC hastalarının zayıf hayatta kalma oranı ile ilişkili olduğunu doğruladık. SKA3'ün yok edilmesi, MDA-MB-231 hücre proliferasyonunu ve göçünü azaltırken, SKA3 aşırı ekspresyonu, 
Hs578T hücrelerinin proliferatif ve göç etme kabiliyetini arttırdı. Ayrıca SKA3'ün mitotik çıkışta hücre döngüsü ilerlemesinin düzenlenmesinde rol oynadığını bulduk.

Sonuçlar: Bu sonuçlar, SKA3'ün, hücre döngüsü ilerlemesini teşvik ederek $\mathrm{BC}$ hücre proliferasyonu ve göçü ile ilişkili olduğunu ve BC tedavisi için yeni bir potansiyel terapötik hedef olabileceğini düşündürmektedir.

Anahtar Kelimeler: hücre göçü; hücre proliferasyonu; kötü prognoz; meme kanseri; SKA3.

\section{Introduction}

Breast cancer (BC) is the most commonly diagnosed malignancy in women worldwide [1]. Although BC-associated survival has improved tremendously over the years mainly due to early detection and treatment, it is still the second primary cause of cancer-related deaths [1-3]. This high mortality is mostly associated with excessive proliferation and aberrant cell cycle signals as well as metastatic cancer $[1,4]$. Further identification and understanding about novel targets of cell cycle and proliferation in $\mathrm{BC}$ is important to improve therapeutic strategy and prognosis. Spindle and kinetochoreassociated complex subunit 3 (SKA3) constitutes the SKA complex along with SKA1 and SKA2. SKA3 is involved in the silencing of spindle assembly checkpoint and maintenance of chromosome cohesion during mitosis [5-7]. Interestingly, the oncogenic ability of SKA3 has been reported in several cancers. A study reported that SKA3 overexpression decreased the migration and invasion of a prostate cancer cell line [5-7]. It is also reported that SKA3 expression is correlated with patient outcome and disease progression to aggressive status in several cancers [8]. The present study aimed to identify the role of SKA3 in BC and determine whether SKA3 could be a potential target in $\mathrm{BC}$ treatment.

\section{Materials and methods}

\section{Cell proliferation assay}

Cell proliferation was analysed by 3-(4,5-dimethylthiazol-2-yl)2,5-diphenyltetrazolium bromide (MTT) assay. First, $5 \times 10^{3}$ cells in $100 \mu \mathrm{L}$ of culture medium were seeded in 96-well plates and incubated for one, two, or three days. At each time point, MTT solution was added to the cells for $3 \mathrm{~h}$. After removing the medium, the remaining MTTformazan crystals were dissociated in dimethyl sulfoxide (DMSO) and $\mathrm{OD}_{570}$ was measured with a microplate reader. Cell proliferation was determined by normalising the absolute absorbance values of initial cells and is expressed as a percentage.

\section{Migration assay}

Cell migration was analysed using transwell cell culture inserts $(8 \mu \mathrm{m}$ pore size) (Corning Life Science, MA). Cells starved for $24 \mathrm{~h}\left(1 \times 10^{5}\right.$ cells per transwell) were plated on the upper chamber and incubated to migrate for $4 \mathrm{~h}$. Thereafter, the migrated cells in the under-surface of the insert were fixed with methanol and stained with $0.5 \%$ crystal violet. Stained cells were solubilised in DMSO and $\mathrm{OD}_{570}$ was measured. The experiment was performed independently in triplicates.

\section{Results}

\section{SKA3 expression is correlated with poor survival of $B C$ patients}

To evaluate the role of SKA3 in $\mathrm{BC}$, the correlation between the clinical features of BC patients and SKA3 expression were analysed using breast-tumour gene expression microarray data sets obtained from TCGA and Gene Expression Omnibus (GEO) database. SKA3 expression was significantly increased in breast tumour tissue than in normal breast tissue $(\mathrm{p}<0.001$, Figure $1 \mathrm{~A})$; low SKA3 expression in $\mathrm{BC}$ was significantly correlated with a high relapse-free survival rate of patients $(p<0.001$, Figure 1B). Overall survival rate was significantly increased in low SKA3 expression patient group $(\mathrm{p}<0.001$, Figure 1C). Furthermore, SKA3 expression was significantly associated with histological grade and oestrogen expression, but not with tumour diameter and lymph node status (Figure 1D). Multivariate analysis (using Cox proportional-hazard method) of important clinical features along with SKA3 expression demonstrated that SKA3 expression status, lymph node status, and oestrogen receptors (ER) are negative prognostic factors in the final proportional-hazard model ( $\mathrm{p}=0.008$, Figure $1 \mathrm{E})$, with a hazard ratio of 2.33 between high and low SKA3 expression. Thus, SKA3 expression is a strong negative prognostic factor for survival and might play a critical role in $\mathrm{BC}$ progression.

\section{SKA3 was related to $B C$ cell proliferation and migration}

SKA3 mRNA and protein expression were determined in eight BC cell lines with epithelial-like or mesenchymallike phenotypes using western blotting and RT-qPCR. The clinical features of the eight cell lines are provided in Supplementary Table 1. SKA3 expression was high in MDA-MB-231 cells and low in BT-20, BT-474, Hs578T, and 
A

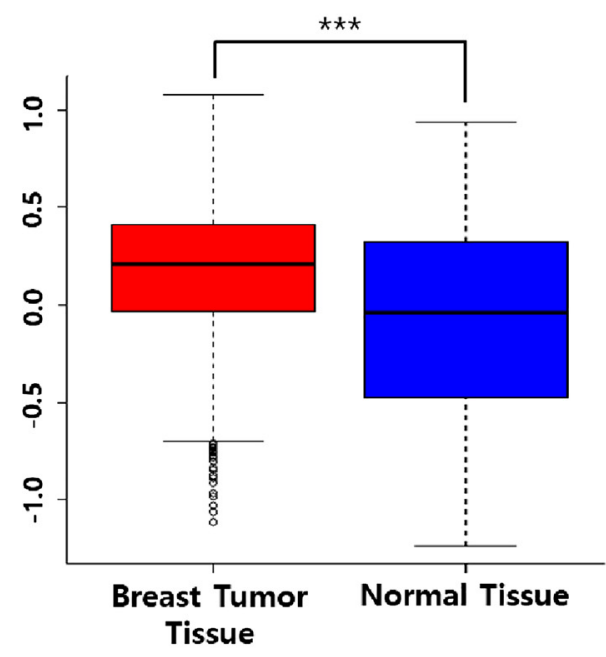

D

\begin{tabular}{lccc}
\hline Clinical features & \multicolumn{2}{c}{$S K A 3$ expression* } & \\
& Low (\%) & High (\%) & $P$ value ** \\
\hline Histologic grade & & & \\
$1-2$ & 42 & 9 & 0.005 \\
3 & 9 & 24 & \\
\hline Tumor diameter & & & \\
$<2 \mathrm{~cm}$ & 16 & 2 & 0.074 \\
$\geq 2 \mathrm{~cm}$ & 55 & 31 & \\
\hline Lymph node status & & & \\
Negative & 33 & 12 & 0.449 \\
Positive & 37 & 21 & \\
\hline ER receptor & & & \\
Negative & 17 & 17 & 0.006 \\
Positive & 53 & 14 & \\
\hline
\end{tabular}

B

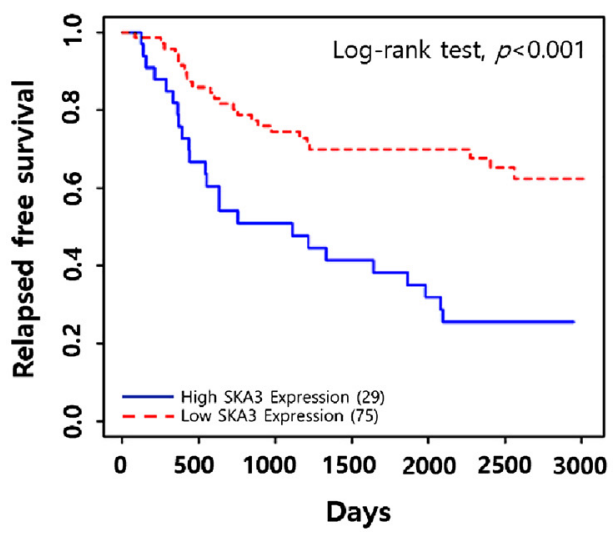

C

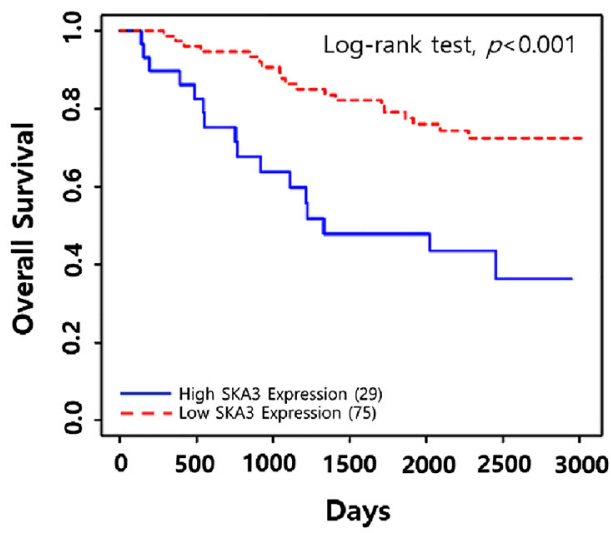

$\mathbf{E}$

\begin{tabular}{cccc}
\hline \multicolumn{1}{c}{ Variable } & Category & HR $^{*}$ & $P$ value \\
\hline \multirow{2}{*}{ Lymph node } & $\begin{array}{l}\text { Negative } \\
\text { Positive }\end{array}$ & 5.10 & $<.001$ \\
\hline \multirow{2}{*}{ ER receptor } & $\begin{array}{l}\text { Negative } \\
\text { Positive }\end{array}$ & 0.46 & 0.017 \\
\hline \multirow{2}{*}{ SKA3 expression } & Low & & \\
& High & 2.33 & 0.008 \\
\hline
\end{tabular}

Figure 1: SKA3 expression was found to be correlated with poor survival of breast cancer patients (A) SKA3 expression is higher in breast tumour tissue than normal tissue. Student's t-test, ${ }^{* \star *} \mathrm{p}<0.001$; (B) Relapse-free survival rate and (C) overall survival rate were analysed by Kaplan-Meier method. (D) Association between SKA3 expression and clinical features, *Low/high SKA3 expression by the best threshold value in survival analysis. **Pearson's chi-squared test. (E) Multivariate survival analysis (proportional-hazards method) of SKA3 in breast cancer, *HR: hazard ratio.

MCF7 cells at the mRNA and protein levels (Figure 2A, B). SKA3 expression level in the cancer cell lines was not correlated with cell phenotype (epithelial-like and mesenchymal-like phenotype) but was associated with biological function such as cell proliferation and migration. To elucidate the biological role of SKA3 in BC, cell proliferation assay was conducted with the eight cell lines. MDA-MB-231 cells showed dramatic cell growth compared to other cell lines (Figure 2C), while Hs578T and BT474 cells rarely proliferated in three days. The cell proliferation rates were associated with SKA3 expression, implying that SKA3 plays a pivotal role in $\mathrm{BC}$ cell proliferation. Furthermore, wound healing assay showed that MDA-MB-231 cells highly expressing SKA3 had better migratory ability than Hs578T cells, which rarely express SKA3 (Figure 2D).

\section{SKA3 knockdown decelerated BC cell proliferation and migration}

To evaluate the function of SKA3 in BC cell proliferation and migration, we generated stable SKA3 knockdown cell lines by lentivirus-mediated SKA3 shRNA introduction into 
A

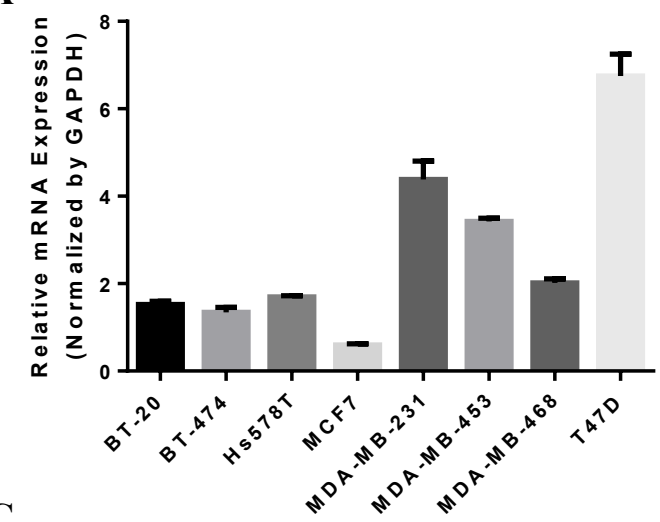

C

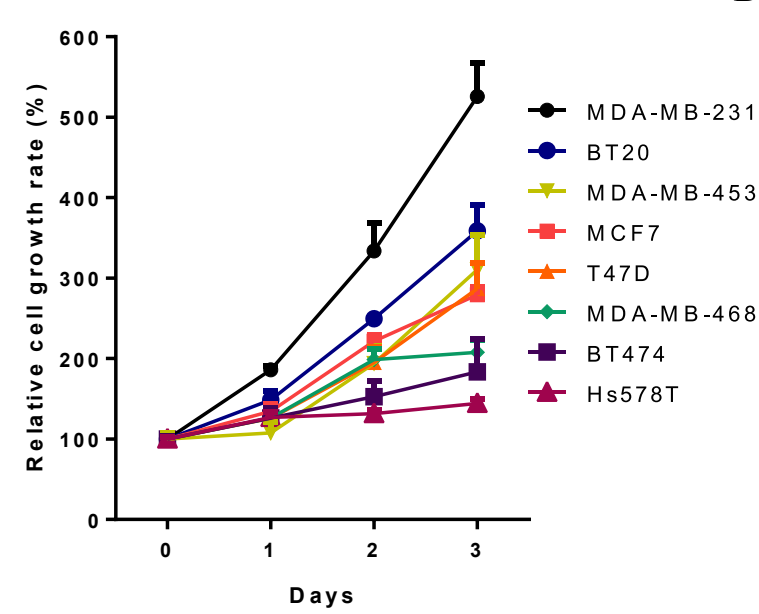

B

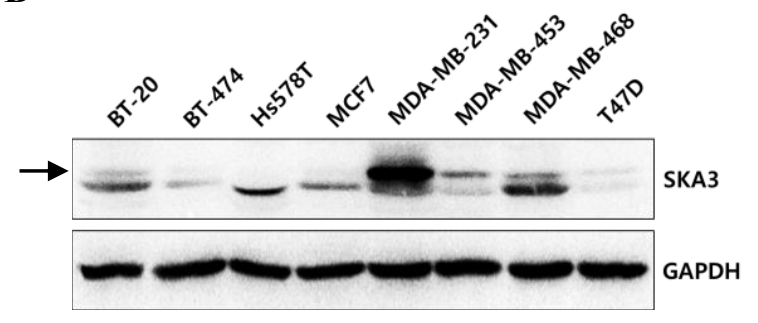

D

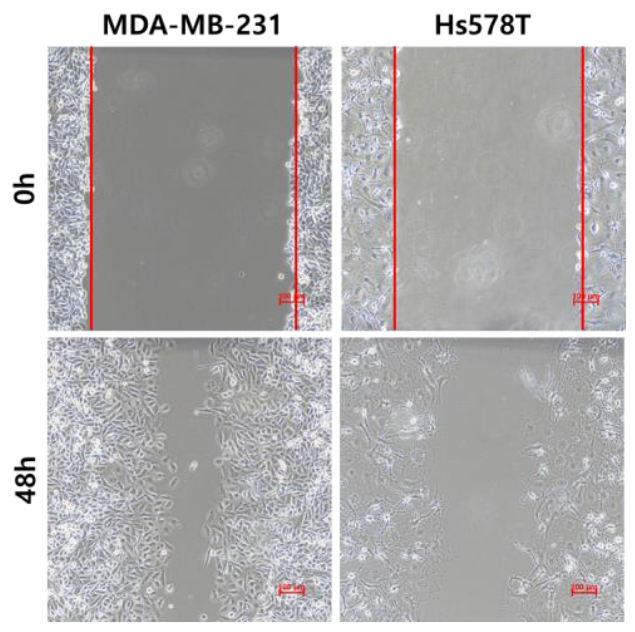

Figure 2: SKA3 was found to be associated with breast cancer cell proliferation and migration. (A) mRNA expression of endogenous SKA3 in eight breast cancer cell lines. GAPDH served as an internal control and its levels were used to normalise the gene expression data. (B) Endogenous SKA3 protein expression in eight breast cancer cell lines. Actin served as an internal control for protein loading. (C) MTT assay with eight breast cancer cell lines. (D) Wound healing assay using MDA-MB-231 and Hs578T cells. Data are shown as mean \pm standard deviation.

MDA-MB-231 cells, which highly express SKA3. The depletion of SKA3 in MDA-MB-231 cells was confirmed using RT-qPCR and western blotting (Figure 3A, B). The influence of SKA3 levels on BC cell proliferation was determined by MTT assay. SKA3 depletion reduced MDA-MB-231 cell growth rate, compared to the control (Figure 3C). Furthermore, transwell migration assay revealed that SKA3 depletion dramatically decreased the migration ability of MDA-MB-231 cells ( $p<0.05$ ) (Figure 3D). The effect of SKA3 function loss on cell migration was further confirmed using wound healing assay, and similar results were obtained; $57 \%$ of the wound area was closed in control cells, while SKA3 knockdown cells retained $64 \%$ of the wound area after $48 \mathrm{~h}(\mathrm{p}<0.05)$ (Figure $3 \mathrm{E})$. To further elucidate role of SKA3 in BC proliferation and migration, cell cycle analyses were conducted using flow cytometry. More than $90 \%$ of cells were synchronised by serum starvation and the accumulated cells in G0/G1 phase were reprogrammed by culturing in medium with $10 \%$ foetal bovine serum. SKA3 knockdown increased G2/M phase arrest (average 16-25\%) and decreased the G0/G1 phase population (average 47-19 \%) in MDA-MB-231 cells (Figure 3F).

\section{SKA3 overexpression expedited BC cell proliferation and migration}

We introduced SKA3 with Flag tag via lentivirus into the low SKA3-expressing Hs578T cells. SKA3 overexpression in Hs578T cells was validated based on the mRNA and protein levels (Figure 4A, B). Cells ectopically expressing SKA3 showed significantly enhanced cell proliferation (vs. control, $\mathrm{p}<0.0001$ ) (Figure 4C). Furthermore, SKA3 
A

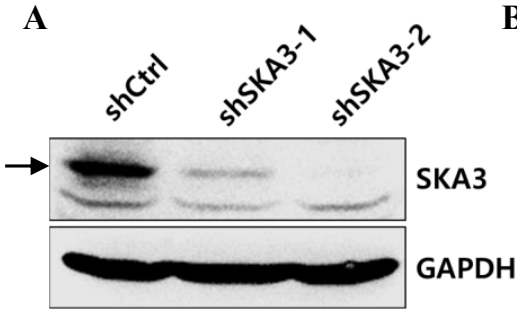

D

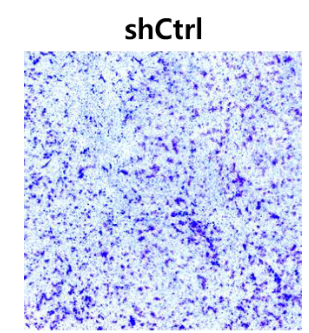

B

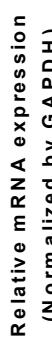

C
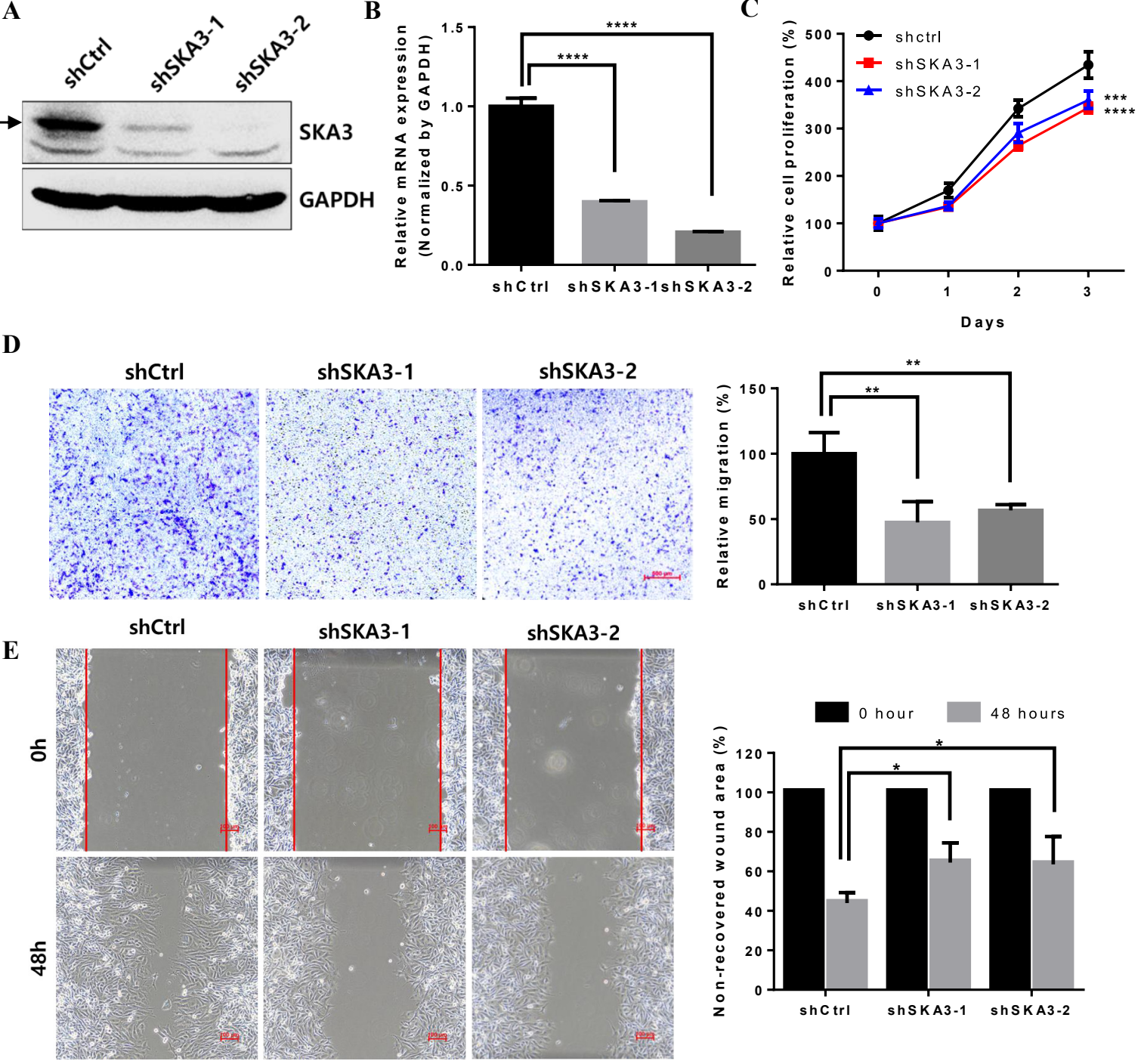

ShSKA3-1

ShSKA3-2

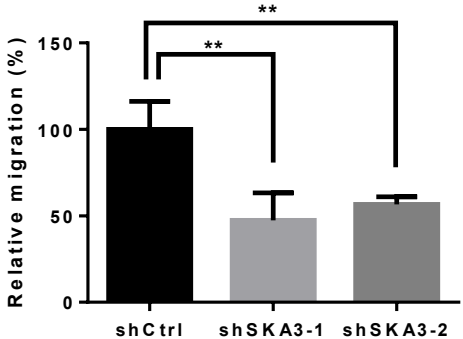

shCtrl shSKA3-1 shSKA3-2

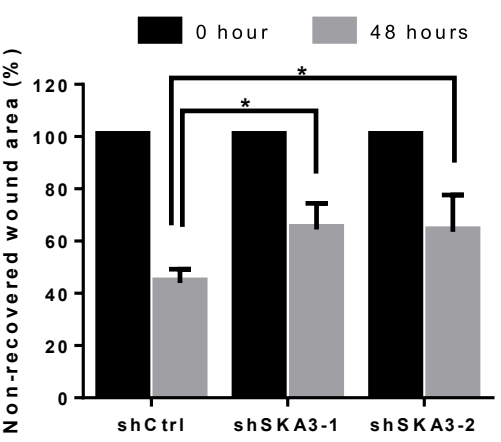

$\mathbf{F}$
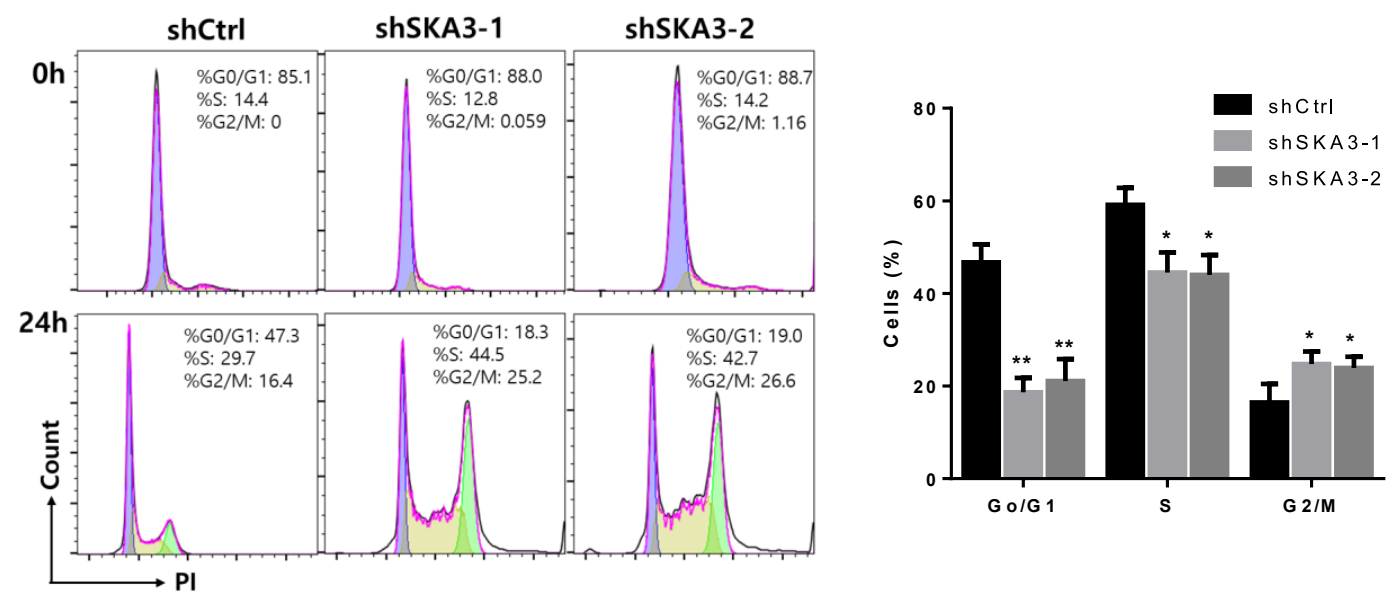

Figure 3: SKA3 knockdown decelerated breast cancer cell proliferation and migration. SKA3 knockdown was confirmed by (A) western blotting and (B) real-time qPCR in MDA-MB-231 cells. (C) MTT (D) transwell migration, and (E) wound healing assays with SKA3 knockdown MDA-MB231 cells. (F) SKA3 knockdown decreased the G1 phase population and increased G2/M phase arrest in MDA-MB 231 cells. Data are expressed as mean \pm standard deviation. Analyses were performed using two-way analysis of variance test for MTT assay and Kruskal-Wallis test for migration and wound healing assay, ${ }^{\star} p<0.01,{ }^{\star *} p<0.01,{ }^{* \star *} p<0.001$. 
A

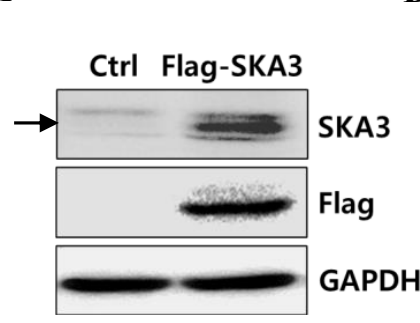

B

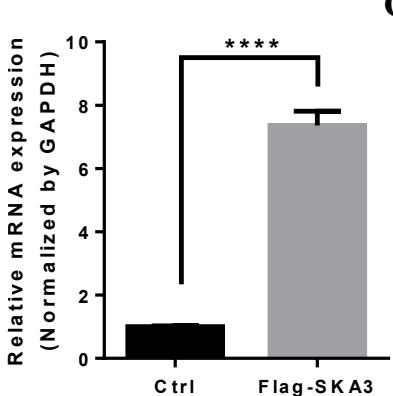

$\mathbf{C}$

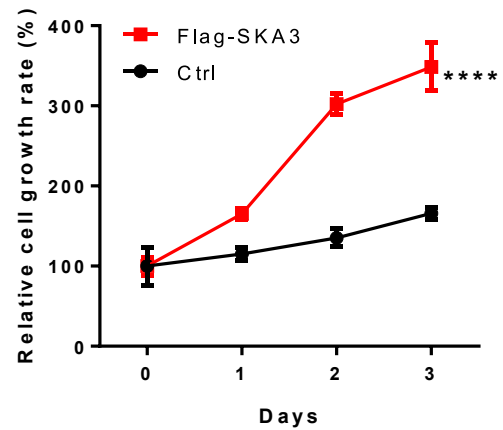

D
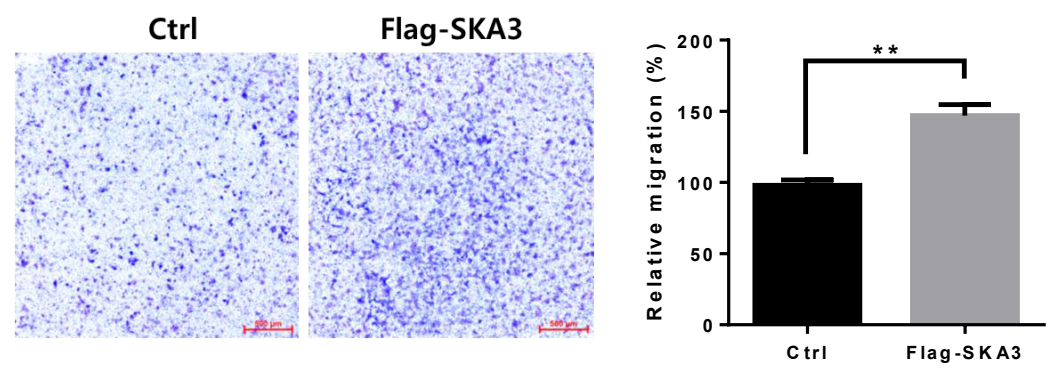

$\mathbf{E}$
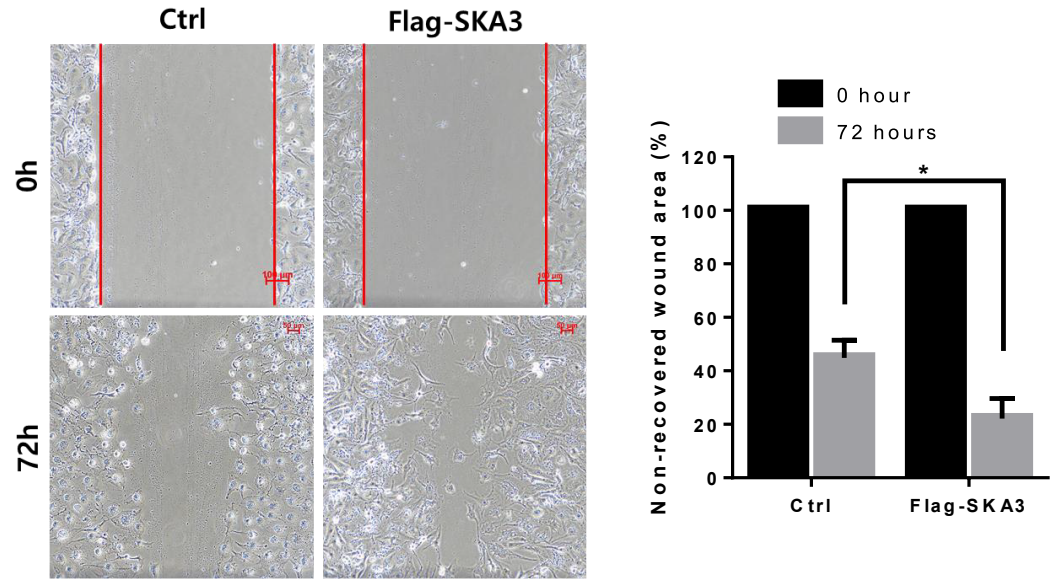

F
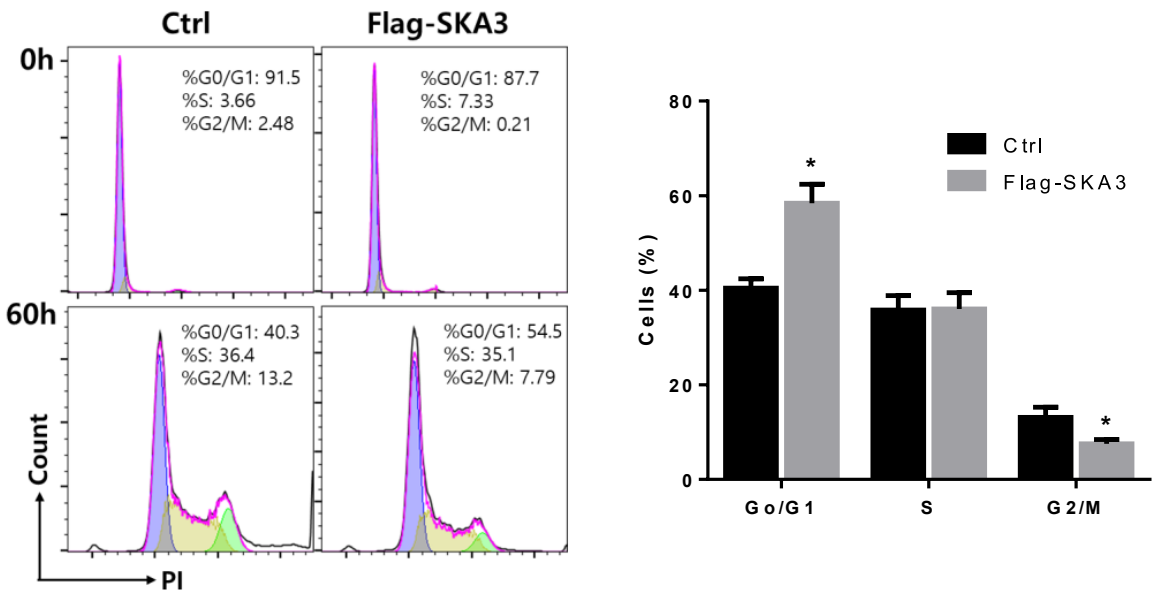

Figure 4: SKA3 overexpression expedited breast cancer cell proliferation and migration. SKA3 overexpression was confirmed by (A) western blotting and (B) real-time qPCR in Hs578T cells. (C) MTT (D) transwell migration, and (E) wound healing assays with SKA3 overexpressed Hs578T cells. (F) SKA3 overexpression increased the G0/G1 phase population and decreased G2/M phase population in Hs578T cells. Data are expressed as mean \pm standard deviation. Analyses were performed using two-way analysis of variance test for MTT assay and Kruskal-Wallis test for migration and wound healing assay, ${ }^{*} p<0.01,{ }^{* \star} p<0.01,{ }^{* \star \star} p<0.001$. 
overexpression significantly increased Hs578T cell migration ability (Figure 4D). The wound healing assay indicated $45 \%$ of non-recovered wound area in control Hs578T cells, while just $22 \%$ of wound area remained in SKA3-overexpressing Hs578T cells after $72 \mathrm{~h}$ of wound creation (Figure 4E). Additionally, SKA3 overexpression markedly increased the G0/G1 phase (average 40-55\%) and decreased the G2/M phase population (average 13-8 $\%$ ) of Hs578T cells (Figure 4F). Taken together, these results indicate that SKA3 plays an essential role in mitotic exit for timely mitotic progression and influenced BC cell proliferation and migration by enhancing cell cycle progression.

\section{Discussion}

Although various factors are involved in cancer development and progression including genetic mutations, inflammation, metabolism, and angiogenesis, uncontrolled proliferation is a common trait of cancer cells, resulting from the dysregulation of the cell cycle $[8,9]$. Mitotic control loss transforms normal cells to cancer cells with oncogenic features, such as chromosomal instability (CIN) and aberrant proliferation. Mitotic exit is composed of multiple precisely regulated steps, including the inactivation of a series of mitotic cyclin-dependent kinases (CDKs) and the activation of ubiquitin ligases. Many mitotic exit regulators are intimately involved in cancer pathogenesis and are potential therapeutic targets [9]. Blocking mitotic exit may provide a new approach for efficient cancer treatment.

Here, we found that SKA3 expression was higher in breast tumour tissues than in normal tissues via the analysis of GEO datasets, and that high levels of SKA3 were correlated with a poor survival rate of BC patients. SKA3 is essential for proper mitotic exit during mitosis as well as meiotic spindle migration and anaphase spindle stability [10]. Somatic mutations in SKA3 were frequently found in $\mathrm{BC}$ tissues using whole genome sequencing and it was shown to impact BC cell growth in RNA interference assays [11]. Recently, SKA3 was shown to be correlated with aggressive disease progression and patient outcome in several cancers including cervical cancer [12]. Furthermore, SKA3 overexpression was associated with colorectal cancer progression, leading to a high rate of CIN in tumours [8-13]. SKA3 depletion in colorectal cancer cells remarkably increased G2/M phase arrest and decreased cell migration, invasion, and growth [13]. In cervical cancer,
SKA3 overexpression accelerated cell migration and proliferation by controlling cell cycle progression through the PI3K-Akt signalling pathway [14]. Furthermore, SKA3 promoted tumour growth by regulating the phosphorylation of CDK2/p53 in hepatocellular carcinoma [15] and lung adenocarcinoma metastasis via the EGFR-PI3K-Akt signalling pathway.

Our study revealed that SKA3 knockdown decreased MDA-MB-231 cell proliferation and migration, while its overexpression enhanced Hs578T cell proliferation and migration, which is consistent with the results found in colorectal cancer cells. Furthermore, our data demonstrated that SKA3 plays a role in cell cycle progression mainly by facilitating mitotic exit. SKA3 knockdown resulted in cells locked in G2/M phase, resulting in slow cell cycle progression. It was also closely correlated with decreased proliferation of MDA-MB-231 cells. SKA3 overexpression accelerated mitotic exit in the cell cycle, showing increased G0/G1 and S phase population in Hs578T cells. The SKA3 silencing-induced interruption of cell cycle progression may result from the impaired function of the SKA complex during mitosis. Taken together, our results revealed that SKA3 may serve as a practical diagnostic and therapeutic target for $\mathrm{BC}$ and may be utilised to predict the prognosis of $\mathrm{BC}$ patients.

In conclusion, our study demonstrates that SKA3 enhances $\mathrm{BC}$ cell proliferation and migration by regulating cell cycle progression in mitotic exit. Although further studies are required to understand the underlying detailed mechanism, SKA3 may be a potential novel therapeutic target and prognostic biomarker for $\mathrm{BC}$.

Acknowledgments: This research was supported by the National Research Foundation of Korea [grant numbers NRF-2018R1A2B6009246, 2018] and the Chung-Ang University Research Scholarship Grants in 2018.

Research funding: This research was supported by the National Research Foundation of Korea [grant numbers NRF-2018R1A2B6009246, 2018] and the Chung-Ang University Research Scholarship Grants in 2018.

Author contributions: S.H., H.N., and JY.K. designed the present study; JY.K., H.K., H.N., and B.K. performed the experiments and collected the data; JJ.K. analysed the GEO databases; and JY.K., H.N., and S.H. analysed the data and wrote the manuscript; All authors critically reviewed and approved the final manuscript.

Competing interest: The authors declare no conflicts of interest. 
Informed consent: Informed consent was obtained from all individuals included in this study.

Ethical approval: The local Institutional Review Board deemed the study exempt from review.

\section{References}

1. Bray F, Ferlay J, Soerjomataram I, Siegel RL, Torre LA, Jemal A. Global cancer statistics 2018: GLOBOCAN estimates of incidence and mortality worldwide for 36 cancers in 185 countries. CA Canc J Clin 2018;68:394-424.

2. Global Cancer Observatory. Cancer Today. Available from: http:// gco.iarc.fr/today/home [Accessed: Dec 2019].

3. Weigelt B, Peterse JL, van’t Veer LJ. Breast cancer metastasis: markers and models. Nat Rev Canc 2005;5:591-602.

4. Hanahan D, Weinberg RA. Hallmarks of cancer: the next generation. Cell 2011;144:646-74.

5. Jeyaprakash AA, Santamaria A, Jayachandran U, Chan YW, Benda C, Nigg EA, et al. Structural and functional organization of the Ska complex, a key component of the kinetochore-microtubule interface. Mol Cell 2012;46:274-86.

6. Daum JR, Wren JD, Daniel JJ, Sivakumar S, McAvoy JN, Potapova TA, et al. Ska3 is required for spindle checkpoint silencing and the maintenance of chromosome cohesion in mitosis. Curr Biol 2009; 19:1467-72.

7. Zhang QH, Qi ST, Wang ZB, Yang CR, Wei YC, Chen L, et al. Localization and function of the Ska complex during mouse oocyte meiotic maturation. Cell Cycle 2012;11:909-16.
8. Lee M, Williams KA, Hu Y, Andreas J, Patel SJ, Zhang S, et al. GNL3 and SKA3 are novel prostate cancer metastasis susceptibility genes. Clin Exp Metastasis 2015;32:769-82.

9. Hu R, Wang MQ, Niu WB, Wang YJ, Liu YY, Liu LY, et al. SKA3 promotes cell proliferation and migration in cervical cancer by activating the PI3K/Akt signaling pathway. Canc Cell Int 2018;18: 183.

10. Chuang TP, Wang JY, Jao SW, Wu CC, Chen JH, Hsiao KH, et al. Over-expression of AURKA, SKA3 and DSN1 contributes to colorectal adenoma to carcinoma progression. Oncotarget 2016;7:45803-18.

11. Jiao X, Hooper SD, Djureinovic T, Larsson C, Warnberg F, TellgrenRoth C, et al. Gene rearrangements in hormone receptor negative breast cancers revealed by mate pair sequencing. BMC Genom 2013;14:165.

12. Hou Y, Wang Z, Huang S, Sun C, Zhao J, Shi J, et al. SKA3 promotes tumor growth by regulating CDK2/P53 phosphorylation in hepatocellular carcinoma. Cell Death Dis 2019;10:929.

13. Hu DD, Chen HL, Lou LM, Zhang H, Yang GL. SKA3 promotes lung adenocarcinoma metastasis through the EGFR-PI3K-Akt axis. Biosci Rep 2020;40:BSR20194335.

14. Williams GH, Stoeber K. The cell cycle and cancer. J Pathol 2012; 226:352-64.

15. Liu X, Chen Y, Li Y, Petersen RB, Huang K. Targeting mitosis exit: a brake for cancer cell proliferation. Biochim Biophys Acta Rev Canc 2019;1871:179-91.

Supplementary material: The online version of this article offers supplementary material (https://doi.org/10.1556/tjb-2020-0032). 